\title{
The role of oral antiviral therapy in hepatitis B-related hepatocellular carcinoma
}

\author{
James Fung ${ }^{1,2,3}$, Kenneth S.H. Chok ${ }^{2,3,4}$ \\ ${ }^{I}$ Department of Medicine, The University of Hong Kong, Hong Kong, China. \\ ${ }^{2}$ The Liver Transplant Center, Queen Mary Hospital, Hong Kong, China. \\ ${ }^{3}$ State Key Laboratory for Liver Research, The University of Hong Kong, Hong Kong, China. \\ ${ }^{4}$ Department of Surgery, The University of Hong Kong, Hong Kong, China.
}

Correspondence to: Dr. James Fung, Department of Medicine, The University of Hong Kong, 102 Pokfulam Road, Hong Kong, China.

E-mail: jfung@gastro.hk

How to cite this article: Fung J, Chok KSH. The role of oral antiviral therapy in hepatitis B-related hepatocellular carcinoma. Hepatoma Res 2017;3:284-93.

\section{Article history: \\ Received: 30 Aug 2017 \\ First Decision: 14 Sep 2017 \\ Revised: 3 Oct 2017 \\ Accepted: 7 Nov 2017 \\ Published: 27 Nov 2017}

Key words:

Antiviral therapy,

hepatitis B virus,

hepatocellular carcinoma

\begin{abstract}
Hepatitis B virus (HBV) is the leading cause of hepatocellular carcinoma (HCC) in places where chronic hepatitis B infection is endemic. Oral nucleos(t)ide analog (NA) therapy can reduce the risk of HCC, but cannot completely prevent its development. For HBV-related HCCs, viral inhibition by NAs can preserve or improve liver function, thereby increasing the chance of therapeutic intervention. After surgical resection, NAs can prevent reactivation of $\mathrm{HBV}$, and also reduce the chance of de novo development of HCC in the remnant liver. For those who undergo liver transplantation, NAs are essential to prevent reactivation and graft hepatitis, but is not likely to prevent HCC recurrence, which is due to metastatic disease. The role of NAs for non-curable advanced HCC is less well defined. These include patients undergoing locoregional therapy, chemotherapy, or palliation. Although antiviral therapy can preserve liver function, which may be compromised by HBV, it is unable to prevent disease progression from HCC. At the time of HCC diagnosis, most patients will already be receiving NAs, and these patients should be maintained on therapy. For patients not on antiviral therapy at the time of HCC diagnosis, the decision to commence therapy is often determined by the stage of HCC and life expectancy. Patients undergoing curative therapy, or locoregional therapy/chemotherapy with reasonable life expectancy, should be commenced on antiviral therapy.
\end{abstract}

\section{INTRODUCTION}

An estimated 240 million worldwide are currently infected with the hepatitis $B$ virus (HBV) and have chronic hepatitis $\mathrm{B}(\mathrm{CHB})^{[1]}$. In regions where $\mathrm{CHB}$ infection remains endemic, HBV remains the leading cause of hepatocellular carcinoma $(\mathrm{HCC})^{[2]}$. Although the exact mechanism of hepatocarcinogenesis remains unclear, it is likely that HBV can promote the oncogenic process both directly and indirectly ${ }^{[3]}$. Direct mechanisms include the integration of HBV DNA into the host genome, leading to genomic instability and malignant transformation ${ }^{[4]}$. The integration of HBV DNA into genes responsible for cellular proliferation and differentiation may lead to uncontrolled cellular proliferation via altered expressions of oncogenes and tumor suppressor genes. In fact, integrated HBV

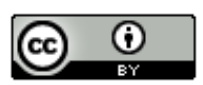

This is an open access article licensed under the terms of Creative Commons Attribution 4.0 International License (https://creativecommons.org/licenses/by/4.0/), which permits unrestricted use, distribution, and reproduction in any medium, as long as the original author is credited and the new creations are licensed under the identical terms.

For reprints contact: service@oaepublish.com

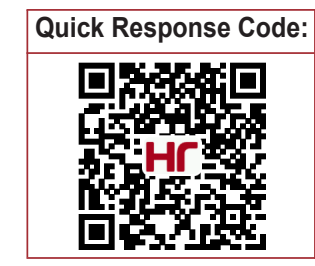


sequences can be observed early in the course of HBV infection, and can be detected in approximately $80 \%$ of HBV-related HCCs ${ }^{[5]}$.

Other wildtype/truncated HBV proteins ( $\mathrm{HBx}, \mathrm{HBc}$, PreS) may also contribute directly towards the development of $\mathrm{HCC}$. $\mathrm{HBx}$ is a regulatory protein that acts as a transcription activator by interacting with viral and host regulatory elements. HBx can interfere with the hepatocyte DNA repair system, cell cycle regulation, and apoptosis ${ }^{[6]}$. Due to the process of DNA integration into the host genome, the HBx gene can be maintained even in the absence of HBV replication ${ }^{[7]}$. The preS1/preS2/S region encodes a transcriptional activator, which may promote hepatocyte proliferation in the presence of pres mutations. Mutations in the HBV surface proteins can also lead to unfolded proteins accumulating in the cytoplasm and subsequent heightened oxidative stress in the endoplasmic reticulum, contributing to hepatocarcinogenesis ${ }^{[8]}$.

Similar to other chronic liver diseases, HBV can also cause HCC indirectly via chronic necro-inflammation, induced apoptosis, and regenerative activity, with subsequent accumulation of mutations, which may be responsible for malignant transformation. During repeated episodes of chronic inflammation and hepatitic flares, activation and interaction between different cytokines may promote immune escape and alter apoptosis. Inflammation-mediated $\mathrm{T}$ cell dysfunction may also impair the immune response against neoplastic cells ${ }^{[9]}$.

From the clinical standpoint, older age, male gender, high viral load, and the presence of cirrhosis are the commonly associated factors for HCC development in $\mathrm{CHB}$ patients ${ }^{[10,11]}$. Of these factors, only viral load can be easily modifiable, and emphasizes the importance of antiviral therapy and its ability to induce complete viral suppression. The REVEAL study demonstrated a linear relationship between serum HBV DNA levels and the risk of developing $\mathrm{HCC}^{[10]}$. This is not surprising, as a high viral load may increase the risk of HCC both directly and indirectly by increasing the chance of oncogenesis with higher rates of HBV integration, and by increasing inflammatory activity respectively. This highlights the importance of viral suppression in preventing $\mathrm{HCC}$ development. As hepatitis $\mathrm{B}$ e-antigen $(\mathrm{HBeAg})$ is a marker of viral replication, its presence has been associated with the development of $\mathrm{HCC}^{[12]}$. More recently, $\mathrm{HBeAg}$ and its precore precursors have been shown to interact with NUMB, leading to reduction of tumor suppressor p53 activity ${ }^{[13]}$. Other HBV serological markers have also been shown to be associated with HCC development, including hepatitis
B core related antigen and hepatitis B surface antigen $(\mathrm{HBsAg})^{[14]}$.

\section{HBV REPLICATION}

During the initial stage of infection, the HBV enters the hepatocyte via a host receptor. Once inside the cytoplasm, the relaxed circular DNA (rcDNA) enters the nucleus to form covalently closed circular DNA (cccDNA $)^{[15]}$. The cccDNA functions as a template for mRNA transcription, which is then transported into the cytoplasm for translation of viral proteins and genomic replication via reverse transcription to form negativestrand DNA. This is followed by formation of positivestrand DNA and rcDNA within the nucleocapsid, which can then undergo further assembly and exported as mature virions, or be recycled back into the nucleus to form cccDNA.

The lack of proofreading mechanism by the HBV polymerase enzyme combined with the high replicative rate leads to high genomic variability with quasi-species containing various mutations. Some of these mutations may be associated with HCC development. These include mutations in the PreS regions as described previously, and drug resistant mutations as result of antiviral therapy. Other mutations associated with higher rate of $\mathrm{HCC}$ include the basal core promoter (BCP) mutation (T1762/A1764) ${ }^{[16,17]}$. The exact mechanism for hepatocarcinogenesis is unclear, although BCP mutations can be associated with disease progression and development of cirrhosis, thereby conferring a higher risk of HCC.

\section{ANTIVIRAL THERAPY FOR CHB}

Presently, the only oral antiviral therapy approved for the treatment of $\mathrm{CHB}$ infection are nucleos(t)ide analogs (NAs). These are HBV polymerase inhibitors which compete with natural nucleotide substrates that target DNA elongation by acting as chain terminators ${ }^{[18]}$. NAs may also target other synthetic functions of HBV polymerase, including priming activity, reverse transcription, and the synthesis of $D N A^{[19]}$. Although interferon- $\alpha 2 b$ and peginterferon- $\alpha 2 a$ are approved for $\mathrm{CHB}$ infection, it is not used in the setting of cirrhosis or HCC. The currently approved NAs for CHB are lamivudine (LAM), adefovir (ADV), telbivudine, entecavir (ETV), tenofovir disoproxil fumarate (TDF), and most recently, tenofovir alafenamide (TAF). All NAs are formulated as fixed dose tablets to be taken once daily. For patients with HCC, the duration of antiviral therapy is usually life-long. Due to the risk of the development of drug-resistant strains, only compounds 
with high potency and high barriers to resistance, such as ETV, TDF, and TAF, should be used ${ }^{[20-22]}$. A high barrier to resistance ensures that long-term use of these drugs is associated with minimal risk of developing drug resistance. The development of drug resistance leads to virological rebound and subsequent hepatitic flares, leading to higher viral load and increase in inflammatory activity respectively, resulting in higher rates of disease progression ${ }^{[23]}$. As a result, the risk of developing HCC may be increased. In a meta-analysis of 14 observational studies with 1,284 patients, the one year overall survival and HCC recurrence were significantly reduced and increased respectively with LAM use when compared with ETV ${ }^{[24]}$. Several studies have also demonstrated a link between the presence of de novo drug resistance mutation and the development of $\mathrm{HCC}$, although the mechanism of tumor development remains unclear ${ }^{[25,26]}$.

Long-term oral antiviral therapy has been shown to be effective in preventing and even reversing cirrhosis ${ }^{[27,28]}$. However, the evidence for preventing HCC is less robust. Although it is likely that antiviral therapy can reduce the incidence of $\mathrm{HCC}$, complete elimination of the risk is not possible ${ }^{[23,29-31]}$. The paradoxical effect of survival of $\mathrm{CHB}$ patients to an older age may increase the risk of development of $\mathrm{HCC}$ by allowing time for detrimental effects caused by HBV carriage and HBV DNA integration. The risk is likely highest for those with established cirrhosis, whereby the liver is already at a carcinogenic stage. This may also explain in part why antiviral therapy is unable to fully prevent the development of HCC. To this end, CHB patients are at a lifelong risk of HCC, and should receive appropriate surveillance to enable earlier diagnosis.

For CHB patients who develop HCC, the role of antiviral therapy is even less well defined. Despite this, most patients will receive antiviral therapy, even though the evidence for its use may not be apparent to the prescriber. Given that antiviral therapy is unable to fully prevent HCC occurrence, a proportion of patients will already be on antiviral therapy at the time of tumor diagnosis. For these patients, it is likely that antiviral therapy will be continued irrespective of the therapeutic approach adopted for management of HCC. For patients not on treatment at the time of HCC diagnosis, most will be commenced on antiviral therapy. However this will often be dependent on the stage and treatability of the HCC. Although the clinical scenario may differ depending upon the stage of HCC and the treatment offered, the general indications of antiviral therapy include preserving liver function and prevention of de novo or recurrent HCCs.

\section{ANTIVIRAL THERAPY FOR HCC PATIENTS UNDERGOING SURGICAL RESECTION}

For patients with preserved liver synthetic function, absence of significant portal hypertension, and resectable tumors, surgical resection remains the best curative option ${ }^{[32]}$. Compared to HCV, HBV may be associated with less risk of recurrence after resection, although the reason for this is unclear ${ }^{[33]}$. However, another study has shown a worse prognosis after resection for HBV-related HCCs compared to nonHBV disease ${ }^{[34]}$. There is evidence to suggest that patients with high viral load at the time of resection are associated with post-resection liver failure and recurrence of $\mathrm{HCC}^{[35-37]}$. Active $\mathrm{HBV}$ replication may also be associated with an increased risk of vascular invasion ${ }^{[38]}$. Given that sufficient remnant liver function is a prerequisite for survival after partial hepatectomy, it would be important to preserve or improve liver function by inhibiting HBV, and to prevent ongoing inflammation or damage which may worsen liver function. For these reasons, all CHB patients with $\mathrm{HCC}$ and planning for resection should receive antiviral therapy prior to surgery.

After resection, patients should remain on long-term antiviral therapy. Surgery itself may predispose patients to HBV reactivation after resection, and is a significant cause of hepatitis and liver failure ${ }^{[39,40]}$. Although the exact mechanism for reactivation is unclear, the stress of partial hepatectomy itself may represent a physiological immunosuppressed state, thereby increasing the risk of reactivation ${ }^{[41]}$. Factors that may increase this risk include general anesthesia, the use of blood transfusion, and intraoperative ischemic injury. Studies in animal models have also documented that duck HBV (DHBV) reactivation occurs following partial hepatectomy in ducks ${ }^{[42]}$. It is possible in this case that hepatocytes remaining in the liver after partial hepatectomy will divide to increase the mass of the liver to preoperative levels and these newly divided hepatocytes provide targets for high levels of DHBV infection and replication, which may be detected as postoperative reactivation.

The highest risk for reactivation is likely observed in patients who are not on antiviral therapy ${ }^{[43]}$. Even for patients with low HBV DNA levels, there is still a risk of postoperative reactivation ${ }^{[44,45]}$. HBV reactivation may worsen liver function, but has also been associated with recurrence of $\mathrm{HCC}$ for those with low viral load at baseline ${ }^{[46]}$.

Recurrence of HCC can occur early (within 2 years) or 
late (beyond 2 years) after resection. Early recurrence is usually due to intrahepatic metastasis and is related more to the characteristics of the primary HCC. In contrast, late recurrence is usually as a result of new primary $\mathrm{HCC}$ from de novo carcinogenesis arising from a premalignant liver. Therefore, the latter is more related to the characteristics of the remnant liver, including the presence of cirrhosis, inflammatory activity, and viral load ${ }^{[47,48]}$. The fibrotic burden and the presence of cirrhosis may increase the chance of recurrence and reduce disease-free and overall survival after resection ${ }^{[49]}$. Hence, the use of antiviral therapy after liver resection may also potentially reduce the risk of HCC recurrence. However, this only applies to new primary HCCs, and antiviral therapy is unlikely able to prevent intra- or extra- hepatic disease due to metastasis. To this end, it is likely that antiviral therapy can help to prevent late rather than early HCC recurrences ${ }^{[50,51]}$. HBV replication and high viral load has been associated with vascular invasion, although this has not been consistently shown ${ }^{[52]}$. Even for patients with low viral load, those with high levels of HBsAg may be at increased risk of HCC recurrence ${ }^{[53,54]}$.

In fact, the use of antiviral therapy has been shown to be independently associated with reduced risk of HCC recurrence. As expected, the benefits were mainly seen with late rather than early recurrences ${ }^{[55-59]}$. In a territory-wide study of $2198 \mathrm{CHB}$ patients with $\mathrm{HCC}$ from Hong Kong, NAs reduced the risk of $\mathrm{HCC}$ recurrence after surgical resection ${ }^{[60]}$. A metaanalysis of 7,619 postoperative HBV-HCC patients showed more favorable 1-, 3-, and 5-year recurrencefree survival with antiviral therapy compared with no treatment ${ }^{[61]}$. In another meta-analysis of 12 studies involving 8,204 HBV-related HCC patients, NA therapy significantly reduced the risk of recurrence and improved both disease-free and overall survival ${ }^{[62]}$. For those with HCC recurrence, a preserved liver function at the time of recurrence via the use of antiviral therapy increased the proportion of patients that can receive curative treatment ${ }^{[63,64]}$. For patients with repeat hepatectomy for recurrent $\mathrm{HCC}$, antiviral therapy was also associated with better long-term prognosis ${ }^{[6]}$.

\section{ANTIVIRAL THERAPY FOR HCC PATIENTS UNDERGOING LIVER TRANSPLANTATION}

For patients who are eligible for liver transplantation, antiviral therapy should be commenced at the time of diagnosis and while they are on the waiting list ${ }^{[66]}$. The use of antiviral therapy in this setting can prevent acute flares and chronic inflammation, and thus may prevent liver decompensation ${ }^{[67]}$. The improvement in liver function may also increase the likelihood of patients being able to receive loco-regional bridging therapy. In addition, viral inhibition prior to liver transplantation may reduce the likelihood of recurrence of HBV infection after transplantation. Lifelong antiviral therapy is required after transplantation to prevent graft hepatitis and graft loss. Although liver transplantation is curative for cirrhosis and HCC, it does not eradicate HBV from the host, likely due to the existence of extrahepatic sites of HBV infection. Prior to the availability of effective antiviral prophylaxis, liver transplantation for $\mathrm{CHB}$ was a relative contraindication due to the high rate of graft hepatitis and subsequent graft loss. The availability of hepatitis B immune globulin (HBIG) together with $L A M$ was a major milestone in preventing HBV recurrence ${ }^{[68]}$. HBIG may bind to HBV surface protein to prevent uptake of HBV into the hepatocytes by host receptors, and may neutralize viral particles through the formation of immune complexes ${ }^{[69]}$. As a form of passive immunoprophylaxis, HBIG has to be administered parenterally at regular intervals to maintain sufficient levels to be effective. Since then, studies have also demonstrated the efficacy of using lower doses, and also replacing HBIG with combination oral antiviral therapy ${ }^{[70,71]}$. With the introduction of more potent NAs with minimal drug resistance, oral antiviral therapy alone without HBIG has also been shown to be highly effective in preventing graft hepatitis together with excellent long-term outcome $e^{[72-75]}$.

The re-appearance of HBsAg and HBV DNA after liver transplantation has been associated with HCC recurrence ${ }^{[76]}$. Previous studies have shown a temporal relationship between the development of posttransplant HCC recurrence and the re-appearance of HBsAg and HBV DNA ${ }^{[77]}$. This suggests an association rather than viral factors being a causative factor for recurrence. Despite adequate antiviral therapy in this setting, the reappearance of HBsAg and HBV DNA suggests that the source is possibly tumor in origin, where the antiviral penetrance may be reduced.

\section{ANTIVIRAL THERAPY FOR HCC PATIENTS UNDERGOING LOCOREGIONAL THERAPY}

For patients ineligible for surgical resection or transplantation, locoregional therapy (LRT) can be potentially curative, and can offer palliative control for inoperable tumors. The effect of LRT on HBV replication, and the effect of antiviral therapy in this setting are not well defined. Transarterial chemoembolization (TACE) is widely used, and can be effective in reducing tumor progression, with improvement in survival ${ }^{[78]}$. The delivery of highly concentrated chemotherapy using LRT results in a high 
intra-tumor concentration of cytotoxic drugs. Although systemic chemotherapy can be associated with HBV reactivation, it is likely that chemotherapy delivered by TACE poses a far less risk. The lipiodol that is widely used to deliver the drug to the tumor allows for the drug to remain concentrated in the tumor for longer periods, thereby reducing the systemic effect. In addition, the risk of HBV reactivation is dependent on the type of chemotherapeutic agent used. Although doxorubicin can cause HBV reactivation, the risk is likely relatively lower than chemotherapy regimens that contain rituximab and high dose steroid ${ }^{[9]}$.

Several risk factors have been identified for HBV reactivation. These include $\mathrm{HBeAg}$ status, viral load, baseline liver function, age, gender, and the intensity of LRT and the use of anthracyclines ${ }^{[80]}$. However, the data for HBV reactivation following TACE remains somewhat inconclusive, with some studies suggesting increase risk, whereas other studies have demonstrated no changes, or even decline in HBV DNA after chemoembolization ${ }^{[81,82]}$. The mechanism underlying the decline in viral load remains unclear, and may be due to the natural fluctuation that is independent of the TACE, or possibly from a reduction in tumor load, which may support HBV replication or impair the host immunity. On the other hand, patients with low viral load are still at risk of HBV reactivation after TACE ${ }^{[83]}$. For patients receiving TACE, prophylactic oral antiviral therapy significantly decreased virological events and hepatitis flares due to reactivation ${ }^{[39,84,85]}$. Achieving undetectable HBV DNA with antiviral therapy has been shown to significantly improve the progression-free survival in patients receiving TACE ${ }^{[86]}$.

For LRT that does not involve chemotherapy, the data is even sparser. HBV reactivation for CHB patients receiving radiofrequency ablation (RFA) is significantly lower than those undergoing surgical resection, although it still can occur ${ }^{[8]]}$. The pre-RFA viral load has been shown to be associated with HCC recurrence after RFA ${ }^{[88]}$, and the use of antiviral therapy after curative RFA was associated with better outcomes regarding $\mathrm{HCC}$ recurrence and overall survival ${ }^{[89]}$. In a case control study of 399 post-RFA patients, antiviral therapy was shown to be an independent factor associated with a decreased risk of HCC recurrence ${ }^{[00]}$.

Therefore, antiviral therapy should be recommended for those receiving LRT with HBV-related HCC. The likely benefits of antiviral therapy are most likely those that can be observed in the short term. These include improving and preserving liver function, suppressing viral load, prevention of reactivation, and subsequently decrease the risk of hepatic failure after $L R T^{[91]}$. The longer-term benefits of antiviral therapy are more difficult to assess, given that a significant proportion will succumb to their underling malignancy independent of the HBV status. However, viral suppression may potentially improve long-term survival by reducing HBV reactivation and $\mathrm{HCC}$ recurrence ${ }^{[92]}$. In a systematic review of 994 patients with unresectable HCC receiving $L R T$, there were significant improvements for progression-free and overall survival in the NA treated group compared with the control group ${ }^{[93]}$.

\section{ANTIVIRAL THERAPY FOR HCC PATIENTS AFTER CHEMOTHERAPYI IMMUNOTHERAPY}

Unlike other solid organ tumors, chemotherapeutic options for HCC remain limited. Sorafenib was approved for the treatment of advanced HCC in 2007. In contrast to the traditional chemotherapy agents, which are associated with immunosuppression, sorafenib may have immunomodulatory function through its effect on $T$ cells, thereby augmenting the immune system ${ }^{[94]}$. Therefore one would anticipate a low risk for HBV reactivation, although there is currently limited data regarding $\mathrm{HBV}$ reactivation with the use of sorafenib. A high baseline viral load has been shown to be an adverse prognostic factor for HBV reactivation and survival in patients with advanced $\mathrm{HCC}$ receiving sorafenib ${ }^{[95,96]}$. In this setting, antiviral therapy may be associated with improve survival, and is a costeffective approach ${ }^{[95,97,98]}$. However, in a recent metaanalysis of 3,256 patients receiving sorafenib for advanced $\mathrm{HCC}$, improvement in survival was only observed in $\mathrm{HCV}$ patients and not those with $\mathrm{HBV}^{[99]}$. Whether these patients were on antiviral therapy, and its effect on survival, was not studied. In 2017, regorafenib, a multikinase inhibitor, was approved for HCC previously treated by sorafenib. The effect of regorafenib on HBV replication is unknown, although it is likely to be similar to sorafenib. It is likely that the long-term outcome for patients with advanced HCC and receiving palliative chemotherapy/immunotherapy will be unchanged by antiviral therapy, as the survival is limited by the advanced nature of the tumor.

\section{ANTIVIRAL THERAPY FOR PATIENTS WITH UNTREATABLE HCC}

For patients with advanced HCC not amenable to treatment, the role of antiviral therapy is limited. Patients will succumb to disease progression arising from the tumor rather than from HBV infection. Therefore, the life expectancy and quality of life is unlikely to be improved with antiviral therapy. 
Those already on antiviral therapy should remain on treatment, as there may still be chance of severe flare with cessation of therapy. For those not on antiviral therapies with advanced HCC for palliation, commencing antiviral therapy at this juncture will be futile for the overwhelming majority. Even in the setting of high viral load and elevated transaminases, it may be difficult to confirm that it is due to HBV-related hepatitis rather than locally advanced infiltrative disease. The decision for antiviral therapy in this setting should be made on a case-by-case basis, taking into account the tumor stage and life expectancy of the patient.

\section{SUMMARY}

Although direct evidence is sparse, there is a general consensus that antiviral therapy can reduce the risk of $\mathrm{HCC}$ in $\mathrm{CHB}$ patients. To date, only one randomized placebo-controlled study has been published, showing a reduction in $\mathrm{HCC}$ and cirrhosis for advanced $\mathrm{CHB}$ patients treated with lamivudine ${ }^{[23]}$. It is unlikely that future placebo-controlled studies will be performed due to ethical reasons. However, there is increasing circumstantial evidence to suggest that long term antiviral therapy will reduce or delay $\mathrm{HCC}^{[100,101]}$. The key to antiviral therapy therefore is starting early, as the presence of advanced fibrosis and cirrhosis at the time of starting therapy is already associated with higher risk of $\mathrm{HCC}^{[102,103]}$.

Once HCC occurs, antiviral therapy is likely still beneficial. The goals of therapy in this instance include HBV DNA inhibition, preservation of liver function, prevention of further disease progression, reduction in the risk of flares, reduction in the risk of HCC recurrence, and hopefully improvement in survival ${ }^{[104]}$. The choice of antiviral therapy will be dependent on the availability, but in general, a highly potent agent with high barriers to resistance should be used. For HBV-related HCC, ETV has been shown to have better overall survival, decompensation-free survival, and recurrence-free survival compared to $\operatorname{LAM}^{[105]}$.

A meta-analysis of 15 studies totaling 8,060 patients with HBV-related HCC after curative therapy showed a better 1-, 3-, and 5-year overall and disease-free survival for those that received $N A s^{[106]}$. In another meta-analysis of 21 studies including 8,072 similar patients, NA therapy significantly improved recurrencefree and overall survival ${ }^{[58]}$. Other systematic reviews of HBV-related HCC patients also demonstrated improve survival and reduced early recurrence after curative treatment ${ }^{[107,108]}$. However, the most important determinant factors for short-term recurrence are likely those related to the tumor. These include the tumor size, number, differentiation, and the presence of lymphovascular permeation. In a large study of 3,855 HBV-related HCC patients, antiviral therapy did not reduce the risk of progressive disease or mortality after adjusting for the tumor status ${ }^{[109]}$.

For those undergoing liver transplantation, recurrence of HCC after transplantation is likely related to pretransplant tumor factors, rather than from HBV-related factors. Despite this, antiviral therapy is essential for $\mathrm{CHB}$ patients to prevent graft loss from reactivation of hepatitis B.

The role of antiviral therapy for those undergoing palliation is less clear, and is likely determined by the stage of $\mathrm{HCC}$ and the life expectancy of the patient. It will be prudent to ensure that all HBV-related HCC patients be considered for antiviral therapy, especially with current NAs being extremely safe with minimal side effects and risks. For those with extensive disease and limited life expectancy, where quality of life and survival is determined by HCC rather than HBV infection, the use of NAs is unlikely to be of benefit. For those with less advanced disease and reasonable short-term survival, NAs may preserve underlying liver function and prevent hepatitis flares.

Currently, there are numerous novel agents undergoing development in clinical trials for both HCC and HBV infection. It is likely that NAs will continue to have an important role with viral inhibition. Newer agents will target different sites of the HBV replication cycle, including viral entry, the formation of cccDNA, transcription, viral packaging and assembly, and the release of mature virions ${ }^{[110]}$. These novel therapies may increase the chance of HBsAg and cccDNA clearance, thereby reducing the production of oncogenic proteins, and potentially reducing the risk of developing HCC.

\section{DECLARATIONS}

\section{Authors' contributions}

Concept, literature search, manuscript preparation, manuscript editing, manuscript review: J. Fung

Concept, manuscript preparation, manuscript editing, manuscript review: K.S.H. Chok

\section{Financial support and sponsorship None.}

\section{Conflicts of interest}

There are no conflicts of interest.

\section{Patient consent}

Not applicable. 


\section{Ethics approval Not applicable.}

\section{REFERENCES}

1. Schweitzer A, Horn J, Mikolajczyk RT, Krause G, Ott JJ. Estimations of worldwide prevalence of chronic hepatitis B virus infection: a systematic review of data published between 1965 and 2013. Lancet 2015;386:1546-55.

2. El-Serag HB. Epidemiology of viral hepatitis and hepatocellular carcinoma. Gastroenterology 2012;142:1264-73.e1.

3. Fung J, Lai CL, Yuen MF. Hepatitis B and C virus-related carcinogenesis. Clin Microbiol Infect 2009;15:964-70.

4. Levrero M, Zucman-Rossi J. Mechanisms of HBV-induced hepatocellular carcinoma. J Hepatol 2016;64:S84-101.

5. Sung WK, Zheng H, Li S, Chen R, Liu X, Li Y, Lee NP, Lee WH, Ariyaratne PN, Tennakoon C, Mulawadi FH, Wong KF, Liu AM, Poon RT, Fan ST, Chan KL, Gong Z, Hu Y, Lin Z, Wang G, Zhang Q, Barber TD, Chou WC, Aggarwal A, Hao K, Zhou W, Zhang C, Hardwick J, Buser C, Xu J, Kan Z, Dai H, Mao M, Reinhard C, Wang J, Luk JM. Genome-wide survey of recurrent HBV integration in hepatocellular carcinoma. Nat Genet 2012;44:765-9.

6. Zhang XD, Wang Y, Ye LH. Hepatitis B virus X protein accelerates the development of hepatoma. Cancer Biol Med 2014;11:182-90.

7. Peng Z, Zhang Y, Gu W, Wang Z, Li D, Zhang F, Qiu G, Xie K. Integration of the hepatitis $B$ virus $X$ fragment in hepatocellular carcinoma and its effects on the expression of multiple molecules: a key to the cell cycle and apoptosis. Int J Oncol 2005;26:467-73.

8. Wang HC, Huang W, Lai MD, Su IJ. Hepatitis B virus pre-S mutants, endoplasmic reticulum stress and hepatocarcinogenesis. Cancer Sci 2006;97:683-8.

9. Zamarron BF, Chen W. Dual roles of immune cells and their factors in cancer development and progression. Int J Biol Sci 2011;7:651-8.

10. Chen CJ, Yang HI, Su J, Jen CL, You SL, Lu SN, Huang GT, Iloeje UH. Risk of hepatocellular carcinoma across a biological gradient of serum hepatitis B virus DNA level. JAMA 2006;295:65-73.

11. Chen G, Lin W, Shen F, Iloeje UH, London WT, Evans AA. Past HBV viral load as predictor of mortality and morbidity from HCC and chronic liver disease in a prospective study. Am J Gastroenterol 2006;101:1797-803.

12. Yang HI, Lu SN, Liaw YF, You SL, Sun CA, Wang LY, Hsiao CK, Chen PJ, Chen DS, Chen CJ. Hepatitis B e antigen and the risk of hepatocellular carcinoma. N Engl J Med 2002;347:168-74.

13. Liu D, Cui L, Wang Y, Yang G, He J, Hao R, Fan C, Qu M, Liu Z, Wang M, Chen L, Li H, Guo D. Hepatitis B e antigen and its precursors promote the progress of hepatocellular carcinoma by interacting with NUMB and decreasing p53 activity. Hepatology 2016;64:390-404.

14. Tada T, Kumada T, Toyoda H, Kiriyama S, Tanikawa M, Hisanaga Y, Kanamori A, Kitabatake S, Yama T, Tanaka J. HBcrAg predicts hepatocellular carcinoma development: an analysis using timedependent receiver operating characteristics. J Hepatol 2016;65:48-56.

15. Seeger C, Mason WS. Molecular biology of hepatitis B virus infection. Virology 2015;479-480:672-86.

16. Yang Z, Zhuang L, Lu Y, Xu Q, Tang B, Chen X. Naturally occurring basal core promoter A1762T/G1764A dual mutations increase the risk of HBV-related hepatocellular carcinoma: a meta-analysis. Oncotarget 2016;7:12525-36.

17. Kao JH, Chen PJ, Lai MY, Chen DS. Basal core promoter mutations of hepatitis B virus increase the risk of hepatocellular carcinoma in hepatitis B carriers. Gastroenterology 2003;124:327-34.

18. Menendez-Arias L, Alvarez M, Pacheco B. Nucleoside/nucleotide analog inhibitors of hepatitis B virus polymerase: mechanism of action and resistance. Curr Opin Virol 2014:1-9.

19. Seifer M, Hamatake R, Colonno R, Standring D. In vitro inhibition of hepadnavirus polymerases by the triphosphates of BMS-200475 and lobucavir. Antimicrob Agents Chemother 1998;42:3200-8.

20. Terrault NA, Bzowej NH, Chang KM, Hwang JP, Jonas MM, Murad MH; American Association for the Study of Liver Disease. AASLD guidelines for treatment of chronic hepatitis B. Hepatology 2016;63:261-83.

21. European Association for the Study of the Liver. EASL 2017 Clinical Practice Guidelines on the management of hepatitis B virus infection. J Hepatol 2017;67:370-98.

22. Sarin SK, Kumar M, Lau GK, Abbas Z, Chan HL, Chen CJ, Chen DS, Chen HL, Chen PJ, Chien RN, Dokmeci AK, Gane E, Hou JL, Jafri W, Jia J, Kim JH, Lai CL, Lee HC, Lim SG, Liu CJ, Locarnini S, Al Mahtab M, Mohamed R, Omata M, Park J, Piratvisuth T, Sharma BC, Sollano J, Wang FS, Wei L, Yuen MF, Zheng SS, Kao JH. AsianPacific clinical practice guidelines on the management of hepatitis B: a 2015 update. Hepatol Int 2016;10:1-98.

23. Liaw YF, Sung JJ, Chow WC, Farrell G, Lee CZ, Yuen H, Tanwandee T, Tao QM, Shue K, Keene ON, Dixon JS, Gray DF, Sabbat J. Lamivudine for patients with chronic hepatitis B and advanced liver disease. $N$ Engl J Med 2004;351:1521-31.

24. Zhou HY, Luo Y, Chen WD, Gong GZ. Hepatitis B virus mutation may play a role in hepatocellular carcinoma recurrence: a systematic review and meta-regression analysis. $J$ Gastroenterol Hepatol 2015;30:977-83.

25. Yang J, Chen X, Zhang H, Chen G. HBV genotype C strains with spontaneous YMDD mutations may be a risk factor for hepatocellular carcinoma. J Med Virol 2014;86:913-7.

26. Yang JH, Zhang H, Chen XB, Chen G, Wang X. Relationship between hepatocellular carcinoma and hepatitis B virus genotype with spontaneous YMDD mutations. World J Gastroenterol 2013;19:38615.

27. Chang TT, Liaw YF, Wu SS, Schiff E, Han KH, Lai CL, Safadi R, Lee SS, Halota W, Goodman Z, Chi YC, Zhang H, Hindes R, Iloeje U, Beebe S, Kreter B. Long-term entecavir therapy results in reversal of fibrosis/cirrhosis and continued histologic improvement in chronic hepatitis B patients. Hepatology 2010;52:886-93.

28. Marcellin P, Gane E, Buti M, Afdhal N, Sievert W, Jacobson IM, Washington MK, Germanidis G, Flaherty JF, Schall RA, Bornstein JD, Kitrinos KM, Subramanian GM, McHutchison JG, Heathcote EJ. Regression of cirrhosis during treatment with tenofovir disoproxil fumarate for chronic hepatitis B: a 5-year open-label follow-up study. Lancet 2013;381:468-75.

29. Hosaka T, Suzuki F, Kobayashi M, Seko Y, Kawamura Y, Sezaki H, Akuta N, Suzuki Y, Saitoh S, Arase Y, Ikeda K, Kobayashi M, Kumada H. Long-term entecavir treatment reduces hepatocellular carcinoma incidence in patients with hepatitis B virus infection. Hepatology 2013;58:98-107.

30. Kim WR, Loomba R, Berg T, Aguilar Schall RE, Yee LJ, Dinh PV, Flaherty JF, Martins EB, Therneau TM, Jacobson I, Fung S, Gurel S, Buti M, Marcellin P. Impact of long-term tenofovir disoproxil fumarate on incidence of hepatocellular carcinoma in patients with chronic hepatitis B. Cancer 2015;121:3631-8.

31. Wu CY, Lin JT, Ho HJ, Su CW, Lee TY, Wang SY, Wu C, Wu JC. Association of nucleos(t)ide analogue therapy with reduced risk of hepatocellular carcinoma in patients with chronic hepatitis B: a nationwide cohort study. Gastroenterology 2014;147:143-51.e5.

32. Torzilli G, Belghiti J, Kokudo N, Takayama T, Capussotti L, Nuzzo G, Vauthey JN, Choti MA, De Santibanes E, Donadon M, Morenghi E, Makuuchi M. A snapshot of the effective indications and results of surgery for hepatocellular carcinoma in tertiary referral centers: is it 
adherent to the EASL/AASLD recommendations? An observational study of the HCC East-West study group. Ann Surg 2013;257:929-37.

33. Sasaki K, Shindoh J, Nishioka Y, Margonis GA, Sugawara T, Andreatos N, Hashimoto M, Pawlik TM. Impact of viral etiology on postoperative de novo recurrence after hepatectomy for hepatocellular carcinoma in cirrhotic patients. J Gastrointest Surg 2017;21:487-95.

34. Li Z, Zhao X, Jiang P, Xiao S, Wu G, Chen K, Zhang X, Liu H, Han $\mathrm{X}$, Wang S, Li X. HBV is a risk factor for poor patient prognosis after curative resection of hepatocellular carcinoma: a retrospective casecontrol study. Medicine (Baltimore) 2016;95:e4224.

35. Chen X, Wu F, Liu Y, Lou J, Zhu B, Zou L, Chen W, Gong J, Wang Y, Zhong R. The contribution of serum hepatitis B virus load in the carcinogenesis and prognosis of hepatocellular carcinoma: evidence from two meta-analyses. Oncotarget 2016;7:49299-309.

36. Huang G, Lau WY, Shen F, Pan ZY, Fu SY, Yang Y, Zhou WP, Wu MC. Preoperative hepatitis B virus DNA level is a risk factor for postoperative liver failure in patients who underwent partial hepatectomy for hepatitis B-related hepatocellular carcinoma. World $J$ Surg 2014;38:2370-6.

37. Hung IF, Poon RT, Lai CL, Fung J, Fan ST, Yuen MF. Recurrence of hepatitis B-related hepatocellular carcinoma is associated with high viral load at the time of resection. Am J Gastroenterol 2008;103:166373.

38. Wei X, Li N, Li S, Shi J, Guo W, Zheng Y, Cheng S. Hepatitis B virus infection and active replication promote the formation of vascular invasion in hepatocellular carcinoma. BMC Cancer 2017;17:304.

39. Lao XM, Luo G, Ye LT, Luo C, Shi M, Wang D, Guo R, Chen M, Li S, Lin X, Yuan Y. Effects of antiviral therapy on hepatitis B virus reactivation and liver function after resection or chemoembolization for hepatocellular carcinoma. Liver Int 2013;33:595-604.

40. Huang G, Lai EC, Lau WY, Zhou WP, Shen F, Pan ZY, Fu SY, Wu MC. Posthepatectomy HBV reactivation in hepatitis B-related hepatocellular carcinoma influences postoperative survival in patients with preoperative low HBV-DNA levels. Ann Surg 2013;257:490-505.

41. Xie ZB, Zhu SL, Peng YC, Chen J, Wang XB, Ma L, Bai T, Xiang BD, Li LQ, Zhong JH. Postoperative hepatitis B virus reactivation and surgery-induced immunosuppression in patients with hepatitis B-related hepatocellular carcinoma. J Surg Oncol 2015;112:634-42.

42. Qiao M, Gowans EJ, Burrell CJ. Intracellular factors, but not virus receptor levels, influence the age-related outcome of DHBV infection of ducks. Virology 1992;186:517-23.

43. Gong WF, Zhong JH, Lu SD, Wang XB, Zhang QM, Ma L, Zhang ZM, Xiang BD, Li LQ. Effects of antiviral therapy on posthepatectomy HBV reactivation and liver function in HBV DNAnegative patients with HBV-related hepatocellular carcinoma. Oncotarget 2017;8:15047-56.

44. Xie ZB, Wang XB, Fu DL, Zhong JH, Yang XW, Li LQ. Postoperative hepatitis $\mathrm{B}$ virus reactivation in hepatitis B virus-related hepatocellular carcinoma patients with hepatitis B virus DNA levels $<500$ copies/ mL. Onco Targets Ther 2016;9:4593-603.

45. Lee JI, Kim JK, Chang HY, Lee JW, Kim JM, Chung HJ, Kim YS, Lee KS. Impact of postoperative hepatitis B virus reactivation in hepatocellular carcinoma patients who formerly had naturally suppressed virus. J Gastroenterol Hepatol 2014;29:1019-27.

46. Sohn W, Paik YH, Cho JY, Ahn JM, Choi GS, Kim JM, Kwon CH, Joh JW, Sinn DH, Gwak GY, Choi MS, Lee JH, Koh KC, Paik SW, Yoo BC. Influence of hepatitis B virus reactivation on the recurrence of HBV-related hepatocellular carcinoma after curative resection in patients with low viral load. J Viral Hepat 2015;22:539-50.

47. Sohn W, Paik YH, Kim JM, Kwon CH, Joh JW, Cho JY, Gwak GY, Choi MS, Lee JH, Koh KC, Paik SW, Yoo BC. HBV DNA and HBsAg levels as risk predictors of early and late recurrence after curative resection of HBV-related hepatocellular carcinoma. Ann Surg
Oncol 2014;21:2429-35.

48. Wu JC, Huang YH, Chau GY, Su CW, Lai CR, Lee PC, Huo TI, Sheen IJ, Lee SD, Lui WY. Risk factors for early and late recurrence in hepatitis B-related hepatocellular carcinoma. J Hepatol 2009;51:8907.

49. Lee HW, Choi GH, Kim DY, Park YN, Kim KS, Choi JS, Ahn $\mathrm{SH}$, Han KH. Less fibrotic burden differently affects the longterm outcomes of hepatocellular carcinoma after curative resection. Oncology 2017;93:224-32.

50. Wei Q, Tian H, Luo HX, Zhang YC, Deng YN, Yao J, Li H, Chen GH, Yang Y. Better prognosis of hepatic resection combined with antiviral therapy for HBV-related hepatocellular carcinoma with BCLC Stage B/C. Asian J Surg 2017;40:453-62.

51. Ho CM, Lee PH, Shau WY, Ho MC, Wu YM, Hu RH. Survival in patients with recurrent hepatocellular carcinoma after primary hepatectomy: comparative effectiveness of treatment modalities. Surgery 2012;151:700-9.

52. Lei Z, Li J, Wu D, Xia Y, Wang Q, Si A, Wang K, Wan X, Lau WY, Wu M, Shen F. Nomogram for preoperative estimation of microvascular invasion risk in hepatitis B virus-related hepatocellular carcinoma within the milan criteria. JAMA Surg 2016;151:356-63.

53. Zhou HB, Li QM, Zhong ZR, Hu JY, Jiang XL, Wang H, Wang H, Yang B, Hu HP. Level of hepatitis B surface antigen might serve as a new marker to predict hepatocellular carcinoma recurrence following curative resection in patients with low viral load. Am J Cancer Res 2015;5:756-71.

54. Huang G, Lau WY, Zhou WP, Shen F, Pan ZY, Yuan SX, Wu MC. Prediction of hepatocellular carcinoma recurrence in patients with low hepatitis B virus DNA levels and high preoperative hepatitis B surface antigen levels. JAMA Surg 2014;149:519-27.

55. Hung IF, Wong DK, Poon RT, Fong DY, Chui AH, Seto WK, Fung JY, Chan AC, Yuen JC, Tiu R, Choi O, Lai CL, Yuen MF. Risk factors and post-resection independent predictive score for the recurrence of hepatitis B-related hepatocellular carcinoma. PLoS One 2016;11:e0148493.

56. Yin J, Li N, Han Y, Xue J, Deng Y, Shi J, Guo W, Zhang H, Wang $\mathrm{H}$, Cheng S, Cao G. Effect of antiviral treatment with nucleotide/ nucleoside analogs on postoperative prognosis of hepatitis B virusrelated hepatocellular carcinoma: a two-stage longitudinal clinical study. J Clin Oncol 2013;31:3647-55.

57. Wu CY, Chen YJ, Ho HJ, Hsu YC, Kuo KN, Wu MS, Lin JT. Association between nucleoside analogues and risk of hepatitis $\mathrm{B}$ virus-related hepatocellular carcinoma recurrence following liver resection. JAMA 2012;308:1906-14.

58. Liu GM, Huang XY, Shen SL, Hu WJ, Peng BG. Adjuvant antiviral therapy for hepatitis B virus-related hepatocellular carcinoma after curative treatment: a systematic review and meta-analysis. Hepatol Res 2016;46:100-10.

59. Huang G, Lau WY, Wang ZG, Pan ZY, Yuan SX, Shen F, Zhou WP, Wu MC. Antiviral therapy improves postoperative survival in patients with hepatocellular carcinoma: a randomized controlled trial. Ann Surg 2015;261:56-66.

60. Wong GL, Tse YK, Chan HL, Yip TC, Tsoi KK, Wong VW. Oral nucleos(t)ide analogues reduce recurrence and death in chronic hepatitis B-related hepatocellular carcinoma. Aliment Pharmacol Ther 2016;43:802-13.

61. Zhang H, Zhou Y, Yuan G, Zhou G, Yang D, Zhou Y. Antiviral therapy improves the survival rate and decreases recurrences and fatalities in liver cancer patients following curative resection: a meta-analysis. Mol Clin Oncol 2015;3:1239-47.

62. Zhou Y, Zhang Z, Zhao Y, Wu L, Li B. Antiviral therapy decreases recurrence of hepatitis B virus-related hepatocellular carcinoma after curative resection: a meta-analysis. World J Surg 2014;38:2395-402. 
63. Chong CC, Wong GL, Wong VW, Ip PC, Cheung YS, Wong J, Lee KF, Lai PB, Chan HL. Antiviral therapy improves post-hepatectomy survival in patients with hepatitis B virus-related hepatocellular carcinoma: a prospective-retrospective study. Aliment Pharmacol Ther 2015;41:199-208.

64. Ke Y, Ma L, You XM, Huang SX, Liang YR, Xiang BD, Li LQ, Zhong JH. Antiviral therapy for hepatitis B virus-related hepatocellular carcinoma after radical hepatectomy. Cancer Biol Med 2013;10:158-64.

65. Huang S, Xia Y, Lei Z, Zou Q, Li J, Yang T, Wang K, Yan Z, Wan $X$, Shen F. Antiviral therapy inhibits viral reactivation and improves survival after repeat hepatectomy for hepatitis B virus-related recurrent hepatocellular carcinoma. J Am Coll Surg 2017;224:283-93.e4.

66. Fung J. Managing hepatitis B: before and after liver transplantation. Ind J Transpl 2011;5:77-80.

67. Fung J, Lai CL, Yuen MF. Management of chronic hepatitis B in severe liver disease. World J Gastroenterol 2014;20:16053-61.

68. Markowitz JS, Martin P, Conrad AJ, Markmann JF, Seu P, Yersiz H, Goss JA, Schmidt P, Pakrasi A, Artinian L, Murray NG, Imagawa DK, Holt C, Goldstein LI, Stribling R, Busuttil RW. Prophylaxis against hepatitis $\mathrm{B}$ recurrence following liver transplantation using combination lamivudine and hepatitis B immune globulin. Hepatology 1998;28:585-9.

69. Shouval D, Samuel D. Hepatitis B immune globulin to prevent hepatitis B virus graft reinfection following liver transplantation: a concise review. Hepatology 2000;32:1189-95.

70. Gane EJ, Angus PW, Strasser S, Crawford DH, Ring J, Jeffrey GP, McCaughan GW. Lamivudine plus low-dose hepatitis B immunoglobulin to prevent recurrent hepatitis B following liver transplantation. Gastroenterology 2007;132:931-7.

71. Angus PW, Patterson SJ, Strasser SI, McCaughan GW, Gane E. A randomized study of adefovir dipivoxil in place of HBIG in combination with lamivudine as post-liver transplantation hepatitis B prophylaxis. Hepatology 2008;48:1460-6.

72. Fung J, Cheung C, Chan SC, Yuen MF, Chok KS, Sharr W, Dai WC, Chan AC, Cheung TT, Tsang S, Lam B, Lai CL, Lo CM. Entecavir monotherapy is effective in suppressing hepatitis B virus after liver transplantation. Gastroenterology 2011;141:1212-9.

73. Fung J, Chan SC, Cheung C, Yuen MF, Chok KS, Sharr W, Chan AC, Cheung TT, Seto WK, Fan ST, Lai CL, Lo CM. Oral nucleoside/ nucleotide analogs without hepatitis B immune globulin after liver transplantation for hepatitis B. Am J Gastroenterol 2013;108:942-8.

74. Fung J, Wong T, Chok K, Chan A, Cheung TT, Dai J, Sin SL, Ma KW, $\mathrm{Ng} \mathrm{K}, \mathrm{Ng} \mathrm{K}$, Seto WK, Lai CL, Fung Yuen M, Lo CM. Long term outcomes of entecavir monotherapy for chronic hepatitis B after liver transplantation: results up to 8 years. Hepatology 2017;66:1036-44.

75. Fung J, Wong T, Chok K, Chan A, Sin SL, Cheung TT, Dai WC, Ng K, $\mathrm{Ng} \mathrm{K}$, Man K, Seto WK, Lai CL, Yuen MF, Lo CM. Oral nucleos(t) ide analogs alone after liver transplantation in chronic hepatitis $\mathrm{B}$ with preexisting rt204 mutation. Transplantation 2017;101:2391-8.

76. Campsen J, Zimmerman M, Trotter J, Hong J, Freise C, Brown R, Cameron A, Ghobrial M, Kam I, Busuttil R, Saab S, Holt C, Emond J, Stiles J, Lukose T, Chang M, Klintmalm G. Liver transplantation for hepatitis B liver disease and concomitant hepatocellular carcinoma in the United States with hepatitis B immunoglobulin and nucleoside/ nucleotide analogues. Liver Transpl 2013;19:1020-9.

77. Faria LC, Gigou M, Roque-Afonso AM, Sebagh M, Roche B, Fallot G, Ferrari TC, Guettier C, Dussaix E, Castaing D, Brechot C, Samuel D. Hepatocellular carcinoma is associated with an increased risk of hepatitis B virus recurrence after liver transplantation. Gastroenterology 2008;134:1890-9; quiz 2155.

78. Llovet JM, Bruix J. Systematic review of randomized trials for unresectable hepatocellular carcinoma: chemoembolization improves survival. Hepatology 2003;37:429-42.

79. Seto WK, Chan TS, Hwang YY, Wong DK, Fung J, Liu KS, Gill H, Lam YF, Lie AK, Lai CL, Kwong YL, Yuen MF. Hepatitis B reactivation in patients with previous hepatitis $\mathrm{B}$ virus exposure undergoing rituximab-containing chemotherapy for lymphoma: a prospective study. J Clin Oncol 2014;32:3736-43.

80. Seto WK. Hepatitis B virus reactivation during immunosuppressive therapy: appropriate risk stratification. World J Hepatol 2015;7:82530 .

81. Lao XM, Wang D, Shi M, Liu G, Li S, Guo R, Yuan Y, Chen M, Li J, Zhang Y, Lin X. Changes in hepatitis B virus DNA levels and liver function after transcatheter arterial chemoembolization of hepatocellular carcinoma. Hepatol Res 2011;41:553-63.

82. Xu X, Huang P, Tian H, Chen Y, Ge N, Tang W, Yang B, Xia J. Role of lamivudine with transarterial chemoembolization in the survival of patients with hepatocellular carcinoma. J Gastroenterol Hepatol 2014;29:1273-8.

83. Shao W, Zhang F, Cong N, Li J, Song J. The hepatitis B virus reactivation after transarterial chemoembolization in Chinese hepatocellular carcinoma patients with low serum hepatitis B virus DNA level. Ther Clin Risk Manag 2015;11:1367-70.

84. Li X, Zhong X, Chen ZH, Wang TT, Ma XK, Xing YF, Wu DH, Dong M, Chen J, Ruan DY, Lin ZX, Wen JY, Wei L, Wu XY, Lin Q. Efficacy of prophylactic entecavir for hepatitis B virus-related hepatocellular carcinoma receiving transcatheter arterial chemoembolization. Asian Pac J Cancer Prev 2015;16:8665-70.

85. Nagamatsu H, Itano S, Nagaoka S, Akiyoshi J, Matsugaki S, Kurogi J, Tajiri N, Yamasaki S, Koga H, Torimura T, Kumashiro R, Sata M. Prophylactic lamivudine administration prevents exacerbation of liver damage in $\mathrm{HBe}$ antigen positive patients with hepatocellular carcinoma undergoing transhepatic arterial infusion chemotherapy. Am J Gastroenterol 2004;99:2369-75.

86. Li X, Zhong X, Chen ZH, Xing YF, Wu DH, Chen J, Ma XK, Lin Q, Wen JY, Wei L, Wang TT, Ruan DY, Lin ZX, Wu XY, Dong M. Hepatitis B virus DNA negativity acts as a favorable prognostic factor in hepatocellular carcinoma patients. Asian Pac J Cancer Prev 2014;15:9635-41.

87. Dan JQ, Zhang YJ, Huang JT, Chen MS, Gao HJ, Peng ZW, Xu L, Lau WY. Hepatitis B virus reactivation after radiofrequency ablation or hepatic resection for HBV-related small hepatocellular carcinoma: a retrospective study. Eur J Surg Oncol 2013;39:865-72.

88. Sohn W, Paik YH, Lee MW, Rhim H, Lim HK, Cho JY, Gwak GY, Choi MS, Lee JH, Koh KC, Paik SW, Yoo BC. Predisposing factors for recurrence of $\mathrm{HBV}$-related small hepatocellular carcinoma after percutaneous radiofrequency ablation. Scand J Gastroenterol 2014;49:373-80.

89. Sohn W, Kang TW, Choi SK, Jung SH, Lee MW, Lim HK, Cho JY, Shim SG, Sinn DH, Gwak GY, Choi MS, Lee JH, Koh KC, Paik SW, Rhim H, Paik YH. Effect of oral antiviral treatment on long-term outcomes of radiofrequency ablation therapy for hepatitis B virusrelated hepatocellular carcinoma. Oncotarget 2016;7:47794-807.

90. Lee TY, Lin JT, Zeng YS, Chen YJ, Wu MS, Wu CY. Association between nucleos(t)ide analog and tumor recurrence in hepatitis B virus-related hepatocellular carcinoma after radiofrequency ablation. Hepatology 2016;63:1517-27.

91. Yoo SH, Jang JW, Kwon JH, Jung SM, Jang B, Choi JY. Preemptive antiviral therapy with entecavir can reduce acute deterioration of hepatic function following transarterial chemoembolization. Clin $\mathrm{Mol}$ Hepatol 2016;22:458-65.

92. Hann HW, Coben R, Brown D, Needleman L, Rosato E, Min A, Hann RS, Park KB, Dunn S, DiMarino AJ. A long-term study of the effects of antiviral therapy on survival of patients with HBV-associated hepatocellular carcinoma (HCC) following local tumor ablation. 
Cancer Med 2014;3:390-6.

93. He L, Liu X, Zhao Y, Zhang S, Jiang Y, Wang X, Yang Z. Efficacy of nucleot(s)ide analogs therapy in patients with unresectable HBVrelated hepatocellular carcinoma: a systematic review and metaanalysis. Dis Markers 2017;2017:7075935.

94. Nagai H, Mukozu T, Matsui D, Kanekawa T, Kanayama M, Wakui N, Momiyama K, Shinohara M, Iida K, Ishii K, Igarashi Y, Sumino Y. Sorafenib prevents escape from host immunity in liver cirrhosis patients with advanced hepatocellular carcinoma. Clin Dev Immunol 2012;2012:607851.

95. Yang Y, Wen F, Li J, Zhang P, Yan W, Hao P, Xia F, Bi F, Li Q. A high baseline HBV load and antiviral therapy affect the survival of patients with advanced HBV-related HCC treated with sorafenib. Liver Int 2015;35:2147-54.

96. Lim S, Han J, Kim GM, Han KH, Choi HJ. Hepatitis B viral load predicts survival in hepatocellular carcinoma patients treated with sorafenib. J Gastroenterol Hepatol 2015;30:1024-31.

97. Xu L, Gao H, Huang J, Wang H, Zhou Z, Zhang Y, Li S, Chen M. Antiviral therapy in the improvement of survival of patients with hepatitis B virus-related hepatocellular carcinoma treated with sorafenib. J Gastroenterol Hepatol 2015;30:1032-9.

98. Zhang P, Yang Y, Wen F, Wheeler J, Fu P, Li Q. Cost-effectiveness analysis of antiviral therapy in patients with advanced hepatitis $\mathrm{B}$ virus-related hepatocellular carcinoma treated with sorafenib. $J$ Gastroenterol Hepatol 2016;31:1978-85.

99. Jackson R, Psarelli EE, Berhane S, Khan H, Johnson P. Impact of viral status on survival in patients receiving sorafenib for advanced hepatocellular cancer: a meta-analysis of randomized phase III trials. J Clin Oncol 2017;35:622-8.

100. Papatheodoridis GV, Idilman R, Dalekos GN, Buti M, Chi H, van Boemmel F, Calleja JL, Sypsa V, Goulis J, Manolakopoulos S, Loglio A, Siakavelas S, Keskin O, Gatselis N, Hansen BE, Lehretz M, de la Revilla J, Savvidou S, Kourikou A, Vlachogiannakos I, Galanis K, Yurdaydin C, Berg T, Colombo M, Esteban R, Janssen HLA, Lampertico $\mathrm{P}$. The risk of hepatocellular carcinoma is decreasing after the first 5 years of entecavir or tenofovir in Caucasians with chronic hepatitis B. Hepatology 2017;66:1444-53.

101. Kim BH, Lim YS, Kim EY, Kong HJ, Won YJ, Han S, Park S, Hwang JS. Temporal improvement in survival of patients with hepatocellular carcinoma in a hepatitis B virus-endemic population. J Gastroenterol
Hepatol 2017; doi: 10.1111/jgh.13848

102. Shim JJ, Oh CH, Kim JW, Lee CK, Kim BH. Liver cirrhosis stages and the incidence of hepatocellular carcinoma in chronic hepatitis B patients receiving antiviral therapy. Scand J Gastroenterol 2017;52:1029-36.

103. Li ZQ, Hu CL, Yu P, Gu XY, Zhang JJ, Li H, Zhang HY, Lv J, Liu YM, Zeng QL, Yan JY, Yu ZJ, Zhang Y. The development of hepatocarcinoma after long-term antivirus treatment of Chinese patients with chronic hepatitis B virus infection: Incidence, longterm outcomes and predictive factors. Clin Res Hepatol Gastroenterol 2017;41:311-8.

104. Wang Y, Xiang X, Chen L, Cao Z, Bao R, Zhou H, Tang W, Lu J, Lin L, Xie Q, Bao S, Wang H. Randomized clinical trial: nucleos $(\mathrm{t})$ ide analogues improved survival of CHB-related $\mathrm{HCC}$ patients via reducing severity and progression of malignancy. Oncotarget 2016;7:58553-62.

105. Kim JH, Sinn DH, Kim K, Kim H, Gwak GY, Paik YH, Choi MS, Lee JH, Koh KC, Paik SW. Lamivudine versus entecavir for newly diagnosed hepatitis B virus-related hepatocellular carcinoma. Gut Liver 2016;10:939-47.

106. Yuan P, Chen P, Qian Y. Evaluation of antiviral therapy performed after curative therapy in patients with HBV-related hepatocellular carcinoma: an updated meta-analysis. Can J Gastroenterol Hepatol 2016;2016:5234969.

107. Xia BW, Zhang YC, Wang J, Ding FH, He XD. Efficacy of antiviral therapy with nucleotide/nucleoside analogs after curative treatment for patients with hepatitis B virus-related hepatocellular carcinoma: a systematic review and meta-analysis. Clin Res Hepatol Gastroenterol 2015;39:458-68.

108. Sun P, Dong X, Cheng X, Hu Q, Zheng Q. Nucleot(s)ide analogues for hepatitis B virus-related hepatocellular carcinoma after curative treatment: a systematic review and meta-analysis. PLoS One 2014;9:e102761.

109. Yeh YC, Liu CJ, Kuo RN, Lai CL, Shau WY, Chen PJ, Lai MS. Association of adjuvant antiviral therapy with risk of cancer progression and deaths in patients with hepatitis-B-virus-related hepatocellular carcinoma following curative treatment: a nationwide cohort study. PLoS One 2014;9:e102051.

110. Fung J, Lai CL, Seto WK, Yuen MF. Emerging drugs for the treatment of hepatitis B. Expert Opin Emerg Drugs 2016;21:183-93. 